\title{
Halal Tourism: Unique, Simple and Worth It!
}

\author{
Ramdah Radjab \\ Lombok Tourism Polytechnic \\ Ministry of Tourism Affairs of the Republic of Indonesia \\ West Nusa Tenggara, Indonesia \\ ramradjab@gmail.com
}

\begin{abstract}
Lombok is rich of culture, spiritual and natural resources. It is now the destination for millions of foreign tourists and the base of thousand mosques. A large number of them are coming to this island because of its famous halal branding of the world.

The term halal tourism term is mostly regarding to food and beverage services and the hotel amenities such as availabilty of mushalla and the rest is the commitment of management to execute things regarding to moslem base syari'a known as halal or muslim friendly living.

Lombok people and geographical strengths are very supporting. The role of local government with Ulamas to lead people to understand and practice such a concept of conventional tourism blended with halal criteria from The Assembly of Indonesian Ulama.

The current tourism trend is to develop, produce and provide such services and amenities with halal base instead of a new conventional innovation. This seems so peculiar but it happens where people prefer halal to conventional tourism for some reasons: uniqueness (not common), simple (easy to serve), safe/secure (protected), healthy/hygiene (good for human body, mind and soul), beauty (nice and good looking), and trust (firm belief in the reliability, truth, or ability of someone or something), and exclusive (excluding or not admitting other thing, restricted or limited). Thus, halal tourism is worth and expensive which sometimes and it is always costly, not the cheap one.
\end{abstract}

Keywords: halal tourism, moslem friendly tourism, conventional tourism, exclusive and expensive tourism, lombok tourism polythecnic, Ulama.

\section{INTRODUCTION}

Increasing numbers of Muslim tourists traveling around the globe has also generated fast growing industry of Halal Tourism. It is estimated that the number of tourists from Middle East will increase to 69 million by 2020 . This will be massive opportunity for tourism industries worldwide since the Middle East travels, especially from Arab Gulf countries spend more than US \$20 billion annually, and US $\$ 8.5$ billion for accommodation (UNWTO 2020 Vision, 2008; Mohsin, Ramli, \& Alkhulayfi, 2016). Considering a huge potential of Halal tourism, leads Indonesian government to develop Halal tourisms in some areas as Indonesia is the largest Muslim country in the world.

Lombok is one of the islands in Indonesia that becomes one of the three government-designated 'priority' areas to be halal destinations after Aceh and West Sumatra (Varagur, 2017). It is reported that approximately $2.7 \%$ out of 12 million foreign tourists visited halal destinations in Indonesia in 2016, in which the highest increase of visitors occurred in Lombok. Approximately 3 million of domestic and foreign tourists visited Lombok in 2015 (Varagur, 2017). A large number of visitors coming to Lombok because of its famous Halal branding. Nearly all foods served in restaurants are halal. Hotels, beaches, restaurants, and other facilities also have mushalla or prayer rooms. In addition, Lombok is rich of culture, beliefs and natural resources.

The local wisdom and geographical strengths of Lombok are mostly supported by the local government and Ulamas. They have crucial roles to lead local people in terms of their knowledge and attitude in blending the concepts of conventional and Halal tourisms. In addition, Halal tourism activities as well as the industries were also supported by the governor of West Nusa Tenggara with the Decree Number 51 in 2015 (known as PERGUB) and the government of West Nusa Tenggara with the Regulation Number 2 in 2016 (known as PERDA). The other ultimate fact about this Halal tourism is on the 20th of October 2015, when Indonesia (represented by West Nusa Tenggara Province) has been awarded "The World Best Halal Tourism Destination" and "The World Best Halal Honeymoon Tourism Destination" in Abu Dhabi, the United Arab Emirates.

Thus, the current trend of developing, generating and provided services and amenities is also based on Halal concept seems to be peculiar. However, in this era most people prefer Halal tourism due to some reasons: uniqueness (not common), simple (easy to serve), safe/secure (protected), healthy/hygiene (good for human body, mind and soul), beauty (nice and good looking), and trust (firm belief in the reliability, truth, or ability of someone or something), and exclusive (excluding or not admitting other thing, restricted or limited).

\section{HALAL TOURISM CONCEPT}

According to International Union of Muslim Scholars, 'Halal' is defined as "That which is permitted, with respect to which no restriction exists, and the doing of which the law-giver, Allah, is allowed" (Al-Qaradawi, 2013; p.XXV). Based on Islamic teaching called Shari'a law, it can be concluded that Halal means 'permissible' of any activities or practices (Battour \& Ismail, 2016). The term 'Halal' is also one of the morality of human actions in Islam, which are defined as recommended (Mustahab), 
compulsory (Fardl), forbidden (Haram), and dislike (Makruh) (Faruki, 1966; Battour \& Ismail, 2016).

The difference between conventional and Halal tourism is not the activities or locations itself but mostly in the way of the Shari'a law is applied. UNWTO defines conventional tourism as the activities of people in less than a year for business, leisure or other purposes to outside their usual environments (Goeldner \& Ritchie, 2006). Meanwhile, Battour and Ismail (2016) define Halal tourism as any activities or tourism objects that permissible based on Islamic teachings to engage Muslims in tourism industries. These activities and tourism objects consider the Shari'a law as the basis to deliver products and services to the customers especially Muslims, such as Halal trips, Halal resorts, Halal hotels and Halal restaurants.

\section{A. Halal tourism and the power of Ulama}

Development of Halal tourism in Indonesia especially Lombok is regardless a strong influence of Ulama in the tourism destinations. A professor of history at Faculty of Cultural Science, University of Indonesia, Mohammad Iskandar stated that the fatwa from a Kyai or Tuan Guru or Ulama is more influenced than the actions of bupati (regent/major) or local government in this society. Even in many cases, mostly local people believe that the problems occurred in society can only be answered by the Ulama, not by bupati (Republika, May 12, 2017, p.17).

This common situation has placed Ulama at the central position of the society as an honourable and informal leader, particularly Muslim community in the countryside (Djakfar, 2017). This attitude has long existence in Indonesia and has been respected to be a part of local wisdom. By considering the position of Ulama in the central of the largest community, Muslims, has placed Ulama as a front buffer of local wisdom to develop the community. The important role of Ulama in community strengthens due to the existences of many religious traditions, such as aqiqah, tahlilan event, hajj (pilgrimage to the Twin Holy Cities; Mecca and Medina), departure event, natal, mortal and marrital ceremonies and other events which always present tausiyah (religious sermons/speeches) of Ulamas. Therefore, this proofs that there is a strong relationship between the role of Ulamas in society and the growing of local wisdom in Indonesia (Djakfar, 2017).

Furthermore, the annual meeting of IMF - World Bank 2018 in Bali has taken the topic "Strengthening Islamic Economy Through Halal Tourism: Challenges, Opportunities and Prospects" has really been highlighting the real issue of recovery Lombok disaster after the earthquake. Ms. Christine Lagarde, Directress of IMF, once again led the world's governments to focus on halal tourism development, especially in Lombok. Thus, it can be said that halal tourism is one key answer for better and sustainable tourism development.

\section{B. Halal tourism and the concept of uniqueness}

The development of Halal tourism in Indonesia, in line with the development of global Islamic economy particularly the trend of the Halal tourism Industries (Samori et al., 2016). This trend has increased the number of revenue or economic growth across countries for around three years due to increase trips or travels of tourists from Muslim countries. It is reported that the number of foreign tourists visiting Indonesia increased significantly, from 9.3 million in 2014 to 12 million in 2016 (Jaelani, 2017).

The development of the Halal tourism in Indonesia is not far from religious values and practices aspect. Religious values and practices aspects of Indonesian society (especially Muslim community) have been inseparably connected with history and tradition, in which these are a part of diversity of Indonesia. The diversity of cultural and religious heritage of Indonesia, such as language, race, ethnicity and customs can be potentially to be developed for tourism industry. Referring to the diversity, Muslim as the largest community in Indonesia certainly has their own uniqueness to develop as Halal tourism businesses, such as mosque, tomb or grave, palace and culinary (Jaelani, Setyawan, \& Hasyim, 2016, Jaelani, 2017). Take an example, Halal tourism in Lombok has developed significantly due to a uniqueness of this island. This has thousands mosques and a strong culture influenced by Balinese combine with Islamic law. Due to this uniqueness, currently Lombok placed itself with about $87 \%$ of Muslim population as "The World's Best Halal Tourism Destination" in 2015 at an annual Muslim travel industry event in Dubai (Varagur, 2017).

\section{Halal tourism and simplicity}

It is argued that the concept of 'Halal' as a part of Shari'a law and guideline for Muslims have presented itself as a 'grounding' mechanism in everyday life. This mechanism lies in the simplicity and being embedded in the daily life, such as foods, beauty, places, cleanliness and many more (Mukherjee, 2014). Referring to the concept of simplicity, it can be concluded that the mechanism of living by following Shari'a law is not complex as most people thought. This can simply be applied in daily life as well as in tourism industry. This is because in most Muslim daily life, they are used to follow the Shari'a law, which all parts of the law refer to the advantages and great things of life that can be preferable in terms of cleanness, hygiene, and preparing foods than conventional tourism styles.

\section{Halal tourism and its worthy}

In some cases, developing Halal tourism business costs high expenditure for developers as well as it is expensive for some travellers for several reasons. The first is about the foods. Several studies repeatedly emphasise that Halal tourist destinations should prepare Halal food and restaurants well. In terms of the foods and restaurants, these aspects are crucial factors in developing Halal tourism business. In the Muslim majority countries, such 
as Pakistan and Saudi Arabia, individuals can easily purchase and consume Halal food with low risk because these countries have entire legal systems based on Shari'a. However, Indonesia has diversity in culture and religion caused difficulties providing Halal food and beverage with high quality in some tourist destinations, that costs more expenditure in supplying and purchasing the ingredients for Halal food and non-alcoholic beverage (Muhammad, Isa, \& Kifli, 2009; Jafari \& Scott, 2014; Olya \& Al-Ansi, 2018).

Another reason is dealing with Halal compliant accommodation, tours, and destinations. Previous studies state that developing Halal tourism has to understand the role of travel in Islamic life through identifying verbal and non-verbal communication with Muslim tourists, providing segregation of sexes in the tourist facilities, and providing Islamic and cultural events. These will cost more expenses than the conventional tourism especially for the amenities or facilities provided in the tourist destinations.

On the other hand, Halal tourism has become one of the potential economic sources for many countries around the world especially Indonesia with the largest Muslim community in the world. By developing Halal tourism in Indonesia is not only to create many job opportunities and reduce poverty. This also can enhance people knowledge and perception about Islam and the concept of 'Halal' itself based on Shari'a Law (Sunnah and Al-Qur'an).

Adhering Islamic law or principles will bring multiple effects. For instance, by providing Muslim-friendly accommodation also boosts the Halal food industry. By providing Halal food and beverage to be accessed can grow the market segment, in which be worth around US\$ 10 billion annually with growth of $7-10 \%$ per year (Global Islamic Finance Report in Amman, 2018). Furthermore, the services and products provided in Halal tourism industry lead to many opportunities for expansion of tourism industry as well as hospitality. This makes a niche market especially for Non-Muslim tourist who are seeking for health-conscious lifestyle providing in most Halal tourism industry (Stephenson, 2014; Olya \& Al-Ansi, 2018; Radjab, 2018).

\section{CONCLUSION}

Halal tourism has many potencies to be developed and benefits for the largest Muslim country, Indonesia, especially Lombok which becomes one of the priority areas for Halal tourism sustainable development. Developing Halal tourism is not far from the roles of the Ulama as an informal leader of community. Referring to Halal tourism development, it cannot be separated with its concept, uniqueness, and simplicity. Although development of Halal tourism seems so peculiar, it is worth where people prefer halal to conventional tourism.

\section{REFERENCES}

Al-Qaradawi, Y. (2013). The lawful and the prohibited in Islam: Shoruuk International.

Amman. (2018, Sep 03). Halal industry to benefit from IMF-WB bali meeting. Global Data Point. Retrieved from https://search-proquestcom.elibrary.jcu.edu.au/docview/2098628893?acco untid $=16285$

Battour, M., \& Ismail, M. N. (2016). Halal tourism: Concepts, practises, challenges and future. Tourism management perspectives, 19, 150-154. doi https://doi.org/10.1016/j.tmp.2015.12.008

Djakfar, M. (2017). Guarding sharia economy in Indonesia optimization of contemporary Ulama authority and local wisdom. El Harakah, 19(2), 209-226.

doi:http://dx.doi.org.elibrary.jcu.edu.au/10.18860/e 1.v19i2.4433

Faruki, K. (1966). AL-AHKĀM AL-K AM A: The five values. Islamic Studies, 43-98 Goeldner, C. R., \& Ritchie, J. B. (2006). Tourism: Principles, practices, philosophies: John Wiley \& Sons.

Jaelani, A., Setyawan, E., Hasyim, N. (2016), Religious heritage tourism and creative economy in Cirebon: The diversity of religious, cultures and culinary. Journal of Social and Administrative Sciences, 3(1), 63-76. Aavailable from: https://ideas.repec.org/a/ksp/journ4/ v3y2016i1p63-76.html.

Jaelani, A. (2017). Halal Tourism Industry in Indonesia: Potential and Prospects. International Review of Management and Marketing, 7(3), 25-34. https://dx.doi.org/10.2139/ssrn.2899864

Jafari, J., \& Scott, N. (2014). Muslim world and its tourisms. Annals of Tourism Research, 44, 1e19. doi https://doi.org/10.1016/j.annals.2013.08.011

Lombok makes a mark in halal tourism. (2015, December 10). Express Travel World. Retrieved from http://link.galegroup.com.elibrary.jcu.edu.au/apps/ doc/A437144920/ITOF?u=james_cook\&sid=ITOF \&xid $=\mathrm{b} 1 \mathrm{cb} 50 \mathrm{e} 7$

Lombok Post. ( ). Pariwisata Halal Perkuat Ekonomi NTB, 16/10/2018. p 3

Mohsin, A., Ramli, N., \& Alkhulayfi, B. A. (2016). Halal tourism: Emerging opportunities. Tourism Management Perspectives, 19, 137-143. doi https://doi.org/10.1016/j.tmp.2015.12.010

Muhammad, N. M. N., Isa, F. M., \& Kifli, B. C. (2009). Positioning Malaysia as halalhub: Integration role of supply chain strategy and halal assurance system. Asian Social Science, 5(7), 44. Retrieved from http://repo.uum.edu.my/16233/1/110.pdf

Mukherjee, S. R. (2014). Global Halal: meat, money, and religion. Religions, $5(1), \quad 22-75 . \quad$ Doi doi:10.3390/rel5010022

Oktadiana, H., Pearce, P. L., \& Chon, K. (2016). Muslim travellers' needs: What don't we know?. Tourism 
Management Perspectives, 20, 124-130. doi https://doi.org/10.1016/j.tmp.2016.08.004

Olya, H. G., \& Al-ansi, A. (2018). Risk assessment of halal products and services: Implication for tourism industry. Tourism Management, 65, 279-291.doi https://doi.org/10.1016/j.tourman.2017.10.015

Peraturan Daerah Provinsi Nusa Tenggara Barat Nomor 2 Tahun 2016 Tentang Pariwisata Halal

Peraturan Gubernur Provinsi Nusa Tenggara Barat Nomor 51 Tahun 2015 Tentang Wisata Halal

Radjab, R. (2018). Persepsi Pelaku Pariwisata Terkait Penggunaan Bahasa Asing di KEK Mandalika, Individual Research, Politeknik Pariwisata Lombok

Samori, Z., Md Salleh, N.Z., Khalid, M.M. (2016), Current trends in halal tourism: Cases in selected Asian countries. Tourism Management Perspectives, 19, 131-136. Available from: https://scholar.google. com/scholar?cluster $=6748903589466654628 \& \mathrm{hl}=\mathrm{i}$ $\mathrm{d} \&$ as_sdt $=0,5$.

Stephenson, M. L. (2014). Deciphering 'Islamic hospitality': Developments, challenges and opportunities. Tourism Management, 40, 155e164

UNWTO (2008). Facts and figures. Tourism 2020 Vision. Retrieved

from http://www.unwto.org/facts/menu.html

Varagur, K. (2017). Indonesia aims to attract more muslim visitors in 'halal' tourism push. Washington: NPR. Retrieved from https://searchproquestcom.elibrary.jcu.edu.au/docview/1968168939?acco untid $=16285$

"Wisata Halal, Tumpuan Indonesia," in Republika, edition May 12, 2017. 